\title{
BCR wt Allele
}

National Cancer Institute

\section{Source}

National Cancer Institute. BCR wt Allele. NCI Thesaurus. Code C51193.

Human BCR wild-type allele is located in the vicinity of 22 q11.23 and is approximately 138 $\mathrm{kb}$ in length. This allele, which encodes breakpoint cluster region protein, is involved in promoting the activating exchange of GTP for GDP bound by p21 rac or CDC42. The BCR gene forms fusion genes with ABL1 or FGFR1 in chronic myeloid leukemia (CML) and with PDGFRA in a CML-like myeloproliferative disease. The BCR-ABL fusion gene is found in acute myeloid leukemia and acute lymphoblastic leukemia. 